\title{
Standardization of Single Super Phosphate Fertilizer Formulation for Various Hazara Rock Phosphates
}

\author{
Matiullah Khan ${ }^{1 *}$, Humera Arif ${ }^{2}$, Muhammad Rasheed $^{2}$, Motsim Billah ${ }^{3}$ and Shoaib Ahmad
}

${ }^{1}$ Land Resources Research Institute, National Agriculture Research Centre Islamabad, Pakistan; ${ }^{2}$ Pir Mehr Ali Shah, Arid Agriculture University Rawalpindi University Rawalpindi, Pakistan; ${ }^{3}$ University of Haripur, Pakistan.

Abstract | The deficiency of phosphorus (P) is widespread in the soils of Pakistan. Out of 1279 thousand nutrient tons consumption of $\mathrm{P}$ fertilizers in the country during the year $2017-18,85.4 \%$ was imported. The most expansive $\mathrm{P}$ fertilizers' application is continuously increasing the cost of crop production. The huge amount rock phosphate (RP) found in Hazara area of Pakistan can be utilized as $\mathrm{P}$ source by preparing Single Super Phosphate (SSP). The spatial variation in minerology of Hazara RP might have an impact on the availability of phosphorus from these rocks. The experiment was therefore planned to revisit the formulation of SSP for various Hazara locations' rock, for obtaining maximum available P. Three main locations' rock phosphates; Guldania, Kakul and Paswal was collected and ground at 160 mesh level with $\pm 30 \%$ total $\mathrm{P}_{2} \mathrm{O}_{5}$ content were treated with various amounts and dilutions of sulfuric acid. The results showed that application of $\mathrm{H}_{2} \mathrm{SO}_{4} @ 0.6 \mathrm{~L}+50 \%$ dilution (v/v) per kg Guldania $\mathrm{RP}$ gave significantly highest available $\mathrm{P}$ content $(15.61 \%)$, while Kakul RP released maximum P (15.47\%) by application of $\mathrm{H}_{2} \mathrm{SO}_{4} @ 0.60 \mathrm{~L}+55 \%$ v/v dilution, per $\mathrm{kg}$ RP. The Paswal RP released maximum $\mathrm{P}$ by applying $\mathrm{H}_{2} \mathrm{SO}_{4} @ 0.55 \mathrm{~L}+55 \%$ v/v dilution, per $\mathrm{kg}$ RP. The periodic analysis of the reacted RP showed that availability of $\mathrm{P}$ increased with the time span, irrespective of the treatments and locations. However, the highest $\mathrm{P}$ in all reacted RP was recorded on day 90. Beyond day 90, the $\mathrm{P}$ content showed a declining trend, especially in reacted RP of Paswal and Kakul. These results reveal that with the change in mineralogy of $\mathrm{RP}$, the requirement of $\mathrm{H}_{2} \mathrm{SO}_{4}$ for solubilizing $\mathrm{P}$ also changes hence, separate formulation will be workable for all the three locations. These results also indicate that Guldania RP has a good and economical potential for SSP preparation.

Received | November 26, 2019; Accepted | March 18, 2020; Published | August 01, 2020

*Correspondence | Matiullah Khan, Land Resources Research Institute, National Agriculture Research Centre Islamabad, Pakistan; Email: mukhan65pk@yahoo.co.uk

Citation | Khan, M., H. Arif, M. Rasheed, M. Billah and S. Ahmad. 2020. Standardization of single super phosphate fertilizer formulation for various Hazara rock phosphates. Pakistan Journal of Agricultural Research, 33(3): 637-642.

DOI | http://dx.doi.org/10.17582/journal.pjar/2020/33.3.637.642

Keywords | Formulation of SSP, Rock phosphate, Available phosphorus, Sulfuric acid

\section{Introduction}

$\mathrm{R}$ ock phosphate is basically tri-calcium phosphate having unavailable form of phosphorus (Brady, 1990; Das, 2005). Approximately 90\% of rock phosphate are used principally in the manufacture of granular and liquid phosphate fertilizers (Rabchevsky, 1997). The world known rock phosphate reserves are more than 40 billion metric tons which may sustain the world $\mathrm{P}$ fertilizer requirements for more than hundred years. Almost $60 \%$ of the world phosphate is produced by the U.S, North Africa (Morocco and western Sahara) and china for phosphate-fertilizer industry. The share of U.S for rock phosphate production exceeds $28 \%$ (IPNI, 2008). The phosphorus and other elements contents in a rock phosphate determine its 
grade. A high-grade rock phosphate is always desired for manufacturing of fertilizer. Generally, above $30 \% \mathrm{P}_{2} \mathrm{O}_{5}$ content in a rock in accepted for further processing. Generally, impurities of $\left(\mathrm{CaO}, \mathrm{Al}_{2} \mathrm{O}_{3}\right.$, $\mathrm{MgO}, \mathrm{SiO}_{2}, \mathrm{Fe}_{2} \mathrm{O}_{3}$ are found in a rock phosphate depending upon its origin (Chavarria et al., 1981). Iron and aluminum compounds can be tolerated to a specific point although they decrease the available $\mathrm{P}$ content in the product. Silica has generally no such adverse effect other than decreasing the overall $\mathrm{P}$ content in the rock phosphate. The increase in $\mathrm{CaO}$ content increasing the requirement of sulfuric acid for SSP reaction. The huge amount of sulfuric acid application not only decreases available $\mathrm{P}$ content but increases cost as well (Lessis et al., 2015). Chlorine content in rock phosphate up to 0.5 has no such adverse effect on preparation of phosphatic fertilizer especially single super phosphate. Single Super phosphate has the easiest procedure of preparation. According to Khan et al. (2012) if $100 \mathrm{~kg}$ of Hazara rock phosphate is treated with the commercial sulfuric acid of $50 \%$ dilution (volume /volume), after proper processing, it will yield $n / 2$ (where $n=\mathrm{P}_{2} \mathrm{O}_{5}$ content in the rock phosphate), while Fertilizer Manual, 1979 reported that for $100 \mathrm{~kg}$ rock phosphate, 20.15-liter sulfuric acid of $93 \%$ concentration + 2.54-liter water is required.

Pakistani soils have less than $10 \mathrm{mg} \mathrm{kg}^{-1}$ extractable $\mathrm{P}$ content hence marked as $\mathrm{P}$ deficient (Memon, 2005; Rashid, 2005). Heavy doses of P-fertilizers application are therefore recommended to combat the deficiency and get better crop yield. Pakistan annually imports 1090 thousand nutrient tons of P-fertilizers against its requirement of 1279 (GOP, 2018). About 35.7 million nutrient tons RP deposits are present in Hazara Division, Pakistan. The total reserves have the potential to sustain annual production for 30 years, more than the country requires at the moment. (PMDC, 2006). A very minute amount of local reserves is utilized for SSP preparation. During the year 2014 only 15 nutrient tons SSP $\left(14-18 \% \mathrm{P}_{2} \mathrm{O}_{5}\right)$ was prepared in the local industry (GOP, 2018). The least availability of $\mathrm{P}$ from these rock phosphates might be due to the inappropriate formula they are using for SSP preparation. The experiment was therefore conducted to revisit the formulation of $\mathrm{SSP}$ with specific reference to various major location of Hazara rock phosphate and formulate an accurate recipe for the manufacturer.

\section{Materials and Methods}

The laboratory experiment for determination of phosphorus availability from different types of rock phosphate was conducted under lab conditions at Land Resource Research Institute, NARC Islamabad during 2015-2016. Guldania, Kakul and Paswal are the three main areas in Hazara where rock phosphate reserves are found and excavated manually or by small machinery at various scattered locations. Three samples each of stock quality and superior quality were collected from each location of all the three areas. The on-spot quality assessment of these rocks was done using experience of the local persons involved in the business. The samples were ground at particle size 160 mash level. A representative sample of each area were prepared having $\pm 30 \% \mathrm{P}_{2} \mathrm{O}_{5}$ content. Initial analysis of the rock phosphate was conducted at Soil Chemistry Laboratory, National Agriculture Research Centre Islamabad. The total P content and solubility of these rock phosphates were determined as per standard procedure (Olsen and Sommers, 1982) and given in Table 1.

Table 1: Total P content of rock phosphates and their solubility.

$\begin{array}{llll}\text { Rock Phosphates } & \text { Total }_{\mathbf{2}} \mathbf{O}_{\mathbf{5}} \mathbf{( \% )} & \text { WSP (\%) } & \text { CSP (\%) } \\ \text { Guldania } & 30.10 & 0.011 & 4.95 \\ \text { Kakul } & 30.14 & 0.021 & 5.02 \\ \text { Paswal } & 30.12 & 0.009 & 4.65\end{array}$

WSP: water soluble P; CSP: Citrate Soluble P; Means followed by different letters are statically different from each other at $P \leq 0.05$

The experiment was laid out according to the Split plot Complete Randomized Design where RP locations were kept as factor 1 and acid dilution + concentration as factor 2. The experiment was replicated thrice. 200 $\mathrm{g}$ rock phosphate was taken from each of the sample for the SSP reaction. Various combinations of sulfuric acid (specific gravity 1.84) dilutions (volume/volume) and quantity were applied to all the three rock phosphates. Detail of the treatments was as:

Main plot: Locations of Rock phosphates

- Gidania

- Kakul

- Paswal

\section{Subplot}

$\mathrm{T}_{1}=0.6 \mathrm{~L}(120 \mathrm{~mL} / 200 \mathrm{~g})+45 \%$ acid concentration; $\mathrm{T}_{2}=0.6 \mathrm{~L}(120 \mathrm{~mL} / 200 \mathrm{~g})+50 \%$ acid concentration; 
$\mathrm{T}_{3}=0.6 \mathrm{~L}(120 \mathrm{~mL} / 200 \mathrm{~g})+55 \%$ acid concentration; $\mathrm{T}_{4}=0.55 \mathrm{~L}(110 \mathrm{~mL} / 200 \mathrm{~g})+45 \%$ acid concentration; $\mathrm{T}_{5}=0.55 \mathrm{~L}(110 \mathrm{~mL} / 200 \mathrm{~g})+50 \%$ acid concentration; $\mathrm{T}_{6}=0.55 \mathrm{~L}(110 \mathrm{~mL} / 200 \mathrm{~g})+55 \%$ acid concentration.

The dilutions of sulfuric acid were prepared as per standard procedure. 03 Beakers of 2.5 liter were labelled as D-1(45\%), D-2 (50\%) and D-3 (55\%). Dilution-1 (45\%) was prepared by adding 1.375 liter of tap water and then added 1.125-liter sulfuric acid in D-1 beaker with the help of graduated cylinder (1.0 liter) slowly and steadily to minimize fume emission. For D-2 (50\%) preparation, 1.25-liter tape water was put in the beaker followed by 1.25 -liter sulfuric acid. Similarly, D-3 (55\%) was prepared by adding 1.375 -liter acid to 1.125 -liter water in the respective beaker. All the solutions were retained overnight to cool them down to room temperature. Weighed $200 \mathrm{~g}$ sample of each rock phosphate (Guldania, Kakul and Paswal) in plastic bottle and reacted with the respective dilution and quantity of acid as per treatment plan. After the reaction, all the bottles were kept at room temperature for 90 days. Periodic analyses of the reacted rock phosphate were carried out for available $\mathrm{P}$ content (Soltanpour and Workman, 1985) and free acid content (Pakistan Standard, 1961).

\section{Results and Discussions}

\section{Available $P$ concentration after acidulation of rock phosphates}

The reaction of rock phosphate (RP) and acid for preparation of single super phosphate generally proceeds in two stages; in the first stage, sulfuric acid reacts with rock phosphate to form phosphoric acid $\left(\mathrm{H}_{3} \mathrm{PO}_{4}\right)$ and calcium sulfate $\left(\mathrm{CaSO}_{4}\right)$ and in the second step; the $\mathrm{H}_{3} \mathrm{PO}_{4}$ reacts with more rock phosphate to form mono-calcium phosphate or Single Super Phosphate (SSP). The first stage completes rapidly while the second stage continues for several days or weeks (Fertilizer Manual, 1979). Hence, after acidulation with various concentrations of acid, the mixture was kept to complete both the reactions. The F-values for the main plot where Guldania, Kakul and Paswal rock phosphates (Day 15, Day 45 and Day 90) and subplot where various dilution and amount of sulfuric acid applied were compared (Table 2). The Statistical analysis indicated that the effect of main plot and sub-plot were highly significant $(\mathrm{P} \leq 0.01)$ for periodic availability of $\mathrm{P}$ in all the rock phosphate samples. The interaction between main plot where periodic available $\mathrm{P}$ content from RP and subplot where various dilutions of sulfuric acid were kept, was also highly significant $(\mathrm{P} \leq 0.01)$.

Table 2: F-Values of ANOVA for the effect of acid applied on Guldania, Kakul and Paswal.

$\begin{array}{lllll}\text { SOV } & \text { DF } & \begin{array}{l}\text { Available P } \\ \text { Day 15 }\end{array} & \text { Day 45 } & \text { Day 90 } \\ \text { Main-plot } & 2 & 310.38^{* *} & 390.78^{* *} & 1828.01^{* *} \\ \text { Sub-plot } & 5 & 1581.32^{* *} & 2579.54^{* *} & 12412.4^{* *} \\ \text { Interaction } & 10 & 37.13^{* *} & 32.04^{* *} & 87.69^{* *}\end{array}$

SOV: Source of variation; DF: Degree of Freedom; * highly significant at $P \leq 0.01$

\section{Periodic $P$ release from acidulated rock phosphates}

Available P on day 15: The data averaged across the main-plot for comparison of sub-plots' effect, showed highly significant variations in available $\mathrm{P}$ content from various acidulated $\mathrm{RP}$ on day 15 (Table 3 ). The results showed that the significantly highest $(\mathrm{P} \leq 0.01)$ $\mathrm{P}$ content of $(12.06 \%)$ was recorded in treatment $\left(\mathrm{T}_{3}\right)$ where $\mathrm{RP}$ was treated with sulfuric acid dilution $55 \%+0.60 \mathrm{~L}$ and $12.03 \%$ in treatment $\left(\mathrm{T}_{2}\right)$ with sulfuric acid dilution $50 \%+0.60 \mathrm{~L}$ were statistically at par. Whereas treatment $\mathrm{T}_{4}$ gave the lowest $\mathrm{P}$ availability (10.82\%) with sulphuric acid dilution $45 \%$ and the amount $0.55 \mathrm{~L}$. The data averaged across the sub-plot for comparison of main plots' effect where various acidulated rock phosphates showed that highest $\mathrm{P}$ availability of (12.14\%) was recorded in Guldania samples followed by Kakul with (11.90\%) having statistical difference and the lowest available $\mathrm{P}$ content was recorded in Paswal (10.75\%), irrespective of the treatments. The interaction between subplot and main plot was highly significant $(\mathrm{P} \leq 0.01)$ showing highest $\mathrm{P}$ availability of (12.53\%) in the treatment where rock phosphate of Guldania was treated with sulfuric acid dilution 50\%+ $0.60 \mathrm{~L}$. The lowest $\mathrm{P}$ availability (9.99\%) was recorded in Paswal with sulphuric acid dilution $45 \%+0.55 \mathrm{~L}$.

Available $P$ on day 45: The data averaged across the main-plot for comparison of sub-plots' effect showed highly significant variations in available $\mathrm{P}$ content for various RP on day 15 (Table 4). The results showed that significantly the highest $(\mathrm{P} \leq 0.01) \mathrm{P}$ availability of $(14.84 \%)$ was recorded in treatment $\left(\mathrm{T}_{2}\right)$ where sulfuric acid dilution $50 \%+$ amount $0.60 \mathrm{~L}$ and, followed by treatment $\left(\mathrm{T}_{3}\right)$ with $14.83 \%$ where sulfuric acid dilution $55 \%+$ amount $0.60 \mathrm{~L}$ were used, with no 
statistical difference. Whereas, treatment $\mathrm{T}_{4}$ gave the lowest $\mathrm{P}$ availability (13.63\%) where sulphuric acid dilution $45 \%$ amount $0.55 \mathrm{~L}$ was applied. The data averaged across the sub-plot for comparison of mainplots' effect where various rock phosphates showed that highest $\mathrm{P}$ availability of (15.05\%) was recorded in Guldania samples, followed by Kakul with (14.63\%) having statistical difference. The lowest $\mathrm{P}$ availability was recorded in Paswal (13.11\%), irrespective of the treatments. The interaction between sub plot and main plot was highly significant $(\mathrm{P} \leq 0.01)$. The highest $\mathrm{P}$ availability of $(15.58 \%)$ was recorded in the treatment where rock phosphate of Guldania was treated with sulfuric acid dilution $50 \%+$ amount $0.60 \mathrm{~L}$, while the lowest $\mathrm{P}$ availability (12.33\%) was recorded in Paswal with sulphuric acid dilution $50 \%$ and the amount 0.55 L (Fertilizer Manual, 1979).

Table 3: Release of $P$ from various rock phosphates by different acid dilutions and quantity on day 15.

\begin{tabular}{|c|c|c|c|c|c|c|}
\hline \multicolumn{3}{|c|}{ Treatments } & \multicolumn{4}{|c|}{ Available $\mathrm{P}_{2} \mathrm{O}_{5}$ Content } \\
\hline & $\begin{array}{l}\text { Acid (L/ } \\
\operatorname{kg} R P)\end{array}$ & $\begin{array}{l}\mathrm{H}_{2} \mathrm{SO}_{4} \\
\text { Conc. (\%) }\end{array}$ & Guldania & Kakul & Paswal & Mean \\
\hline $\mathrm{T}_{1}$ & 0.60 & 45 & $12.32 \mathrm{~b}$ & $11.62 \mathrm{e}$ & $10.52 \mathrm{i}$ & $11.49 \mathrm{C}$ \\
\hline $\mathrm{T}_{2}$ & 0.60 & 50 & $12.53 \mathrm{a}$ & $12.33 \mathrm{~b}$ & $11.23 \mathrm{f}$ & $12.03 \mathrm{~A}$ \\
\hline $\mathrm{T}_{3}$ & 0.60 & 55 & $12.10 \mathrm{~cd}$ & $12.52 \mathrm{a}$ & $11.54 \mathrm{e}$ & $12.06 \mathrm{~A}$ \\
\hline $\mathrm{T}_{4}$ & 0.55 & 45 & $11.63 \mathrm{e}$ & $10.85 \mathrm{~h}$ & $9.99 \mathrm{j}$ & $10.82 \mathrm{D}$ \\
\hline $\mathrm{T}_{5}$ & 0.55 & 50 & $11.98 \mathrm{~d}$ & $11.97 \mathrm{~d}$ & $10.52 \mathrm{i}$ & $11.47 \mathrm{C}$ \\
\hline $\mathrm{T}_{6}$ & 0.55 & 55 & $12.25 \mathrm{~b}$ & $12.12 \mathrm{c}$ & $11.00 \mathrm{~g}$ & $11.79 \mathrm{~B}$ \\
\hline $\mathrm{Me}$ & & & $12.14 \mathrm{~A}$ & $11.90 \mathrm{~B}$ & $10.79 \mathrm{C}$ & \\
\hline
\end{tabular}

Means followed by different letters are statically different from each other at $P \leq 0.05$

Table 4: Release of $P$ from various rock phosphates by different acid dilutions and quantity on day 45.

\begin{tabular}{llllll} 
Treatments & \multicolumn{4}{c}{ Available $\mathbf{P}_{2} \mathrm{O}_{5}$ Content } \\
$\begin{array}{l}\text { Acid quantity } \\
\text { (L/kg RP) }\end{array}$ & $\begin{array}{l}\mathrm{H}_{2} \mathrm{SO}_{4} \\
\text { Conc. (\%) }\end{array}$ & $\begin{array}{l}\text { Gulda- } \\
\text { nia }\end{array}$ & Kakul & Paswal Mean \\
0.60 & 45 & $14.70 \mathrm{e}$ & $14.54 \mathrm{f}$ & $12.93 \mathrm{k}$ & $14.06 \mathrm{BC}$ \\
0.60 & 50 & $15.58 \mathrm{a}$ & $15.27 \mathrm{c}$ & $13.73 \mathrm{i}$ & $14.84 \mathrm{~A}$ \\
0.60 & 55 & $15.19 \mathrm{c}$ & $15.43 \mathrm{~b}$ & $13.88 \mathrm{~h}$ & $14.83 \mathrm{~A}$ \\
0.55 & 45 & $14.61 \mathrm{ef}$ & $13.64 \mathrm{i}$ & 12.641 & $13.63 \mathrm{E}$ \\
0.55 & 50 & $14.96 \mathrm{~d}$ & $14.31 \mathrm{~g}$ & $12.33 \mathrm{~m} 13.87 \mathrm{D}$ \\
0.55 & 55 & $15.27 \mathrm{c}$ & $14.62 \mathrm{ef}$ & $13.64 \mathrm{j}$ & $14.34 \mathrm{~B}$ \\
Mean & & $15.05 \mathrm{~A}$ & $14.63 \mathrm{~B}$ & $13.11 \mathrm{C}$
\end{tabular}

Means followed by different letters are statically different from each other at $P \leq 0.05$

Available $\mathbf{P}$ content on day 90: The data averaged across the main-plot for comparison of sub-plot's effect showed highly significant variations in available $\mathrm{P}$ content for various RP on day 15 (Table 5). The results showed that significantly the highest $(\mathrm{P} \leq 0.01)$ $\mathrm{P}$ availability of (14.56\%) was recorded in treatment $\left(\mathrm{T}_{3}\right)$ where sulfuric acid dilution $55 \%+$ amount 0.60 $\mathrm{L}$ and $14.53 \%$ was applied followed by treatment $\left(\mathrm{T}_{3}\right)$ with sulfuric acid dilution $50 \%+$ amount 0.60 $\mathrm{L}$ with no statistical difference. Whereas treatment $\mathrm{T}_{4}$ gave the lowest $\mathrm{P}$ availability $(14.18 \%)$ with sulphuric acid dilution $45 \%$ while the amount $0.55 \mathrm{~L}$. The data averaged across the sub-plot for comparison of main-plot's effect where various rock phosphates showed that highest $\mathrm{P}$ availability of $(15.03 \%)$ was recorded in Guldania samples followed by Kakul with (14.63\%) having statistical difference while the lowest $\mathrm{P}$ availability was recorded in Paswal (12.43\%) irrespective of the treatments. The interaction between sub plot and main plot was highly significant $(\mathrm{P} \leq 0.01)$ and the highest $\mathrm{P}$ availability of $(15.61 \%)$ was recorded in the treatment where rock phosphate of Guldania was treated with sulfuric acid dilution $50 \%+$ amount $0.60 \mathrm{~L}$. The lowest $\mathrm{P}$ availability (12.15\%) was recorded in Paswal with sulfuric acid dilution 55\%+ the amount $0.55 \mathrm{~L}$ (Fertilizer Manual, 1979).

Table 5: $P$ Release from various rock phosphates by different acid dilutions and quantity on day 90.

\begin{tabular}{llllll}
$\begin{array}{l}\text { Acid Applied } \\
\text { Acid (L/ }\end{array}$ & $\mathrm{H}_{2} \mathrm{SO}_{4}$ & \multicolumn{4}{l}{ Available $\mathbf{P}_{2} \mathrm{O}_{5}$ Content } \\
kgRP) & $\mathrm{Conc}^{2}(\%)$ & & & & \\
0.60 & 45 & $14.56 \mathrm{~g}$ & $14.46 \mathrm{~h}$ & $12.15 \mathrm{n}$ & $13.72 \mathrm{C}$ \\
0.60 & 50 & $15.61 \mathrm{a}$ & $15.25 \mathrm{c}$ & 12.751 & $14.53 \mathrm{~A}$ \\
0.60 & 55 & $15.15 \mathrm{~d}$ & $15.47 \mathrm{~b}$ & $13.06 \mathrm{k}$ & $14.56 \mathrm{~A}$ \\
0.55 & 45 & $14.65 \mathrm{f}$ & $13.63 \mathrm{j}$ & $12.12 \mathrm{n}$ & $13.46 \mathrm{D}$ \\
0.55 & 50 & $14.98 \mathrm{e}$ & $14.30 \mathrm{i}$ & $11.83 \mathrm{o}$ & $13.70 \mathrm{C}$ \\
0.55 & 55 & $15.22 \mathrm{~cd}$ & $14.66 \mathrm{f}$ & $12.65 \mathrm{~m}$ & $14.18 \mathrm{~B}$ \\
Mean & & $15.03 \mathrm{~A}$ & $14.63 \mathrm{~B}$ & $12.43 \mathrm{C}$ &
\end{tabular}

Means followed by different letters are statically different from each other at $P \leq 0.05$

Free acid content in various SSP

Free acid content in an SSP is the indicator of its quality. The SSPs having more than $5 \%$ free acid content are hygroscopic in nature and makes crumbs while kept in open air. The free acid data recoded in this experiment proved that the free acid content was higher in the treatment where least $\mathrm{P}$ release was recoded either due to excessive acid application than the optimal does or lesser and more diluted (Fertilizer 
Manual, 1979). The free acid content ranged from $4.23 \%$ to $7.68 \%$ among the treatments (Table 6). The trend of free acid content showed that either higher or lower sulfuric acid application caused higher free acid content in prepared SSP on day 90, this might be due to excessive sulfuric acid application or weak acid. The weak acid might not react with rock phosphate to release $\mathrm{P}$ and remained as such in SSP.

Table 6: Free Acid Content in various SSP after reaction on day 90.

Acid Applied Gulda- Kakul Paswal Mean

Acid applied Acid Conc. Free acid contents (\%)

(L/kg RP) (\%)

\begin{tabular}{|c|c|c|c|c|c|}
\hline 0.60 & 45 & $5.52 \mathrm{de}$ & $5.61 d$ & $7.38 \mathrm{ab}$ & $6.17 \mathrm{AB}$ \\
\hline 0.60 & 50 & $4.23 \mathrm{fg}$ & $4.32 \mathrm{fg}$ & $6.79 \mathrm{~b}$ & $5.08 \mathrm{C}$ \\
\hline 0.60 & 55 & $5.01 \mathrm{ef}$ & 4.38 & $6.72 \mathrm{~b}$ & $5.37 \mathrm{BC}$ \\
\hline 0.55 & 45 & $5.35 \mathrm{e}$ & $6.24 \mathrm{c}$ & $7.42 \mathrm{a}$ & $6.34 \mathrm{~A}$ \\
\hline 0.55 & 50 & $5.13 \mathrm{ef}$ & $5.73 \mathrm{~d}$ & $7.68 \mathrm{a}$ & $6.18 \mathrm{AB}$ \\
\hline 0.55 & 55 & $4.5 \mathrm{fg}$ & $5.49 \mathrm{de}$ & $6.84 \mathrm{~b}$ & $5.61 \mathrm{~B}$ \\
\hline Mean & & $4.96 \mathrm{~A}$ & $5.26 \mathrm{~B}$ & $7.13 \mathrm{C}$ & - \\
\hline
\end{tabular}

Means followed by different letters are statically different from each other at $P \leq 0.05$

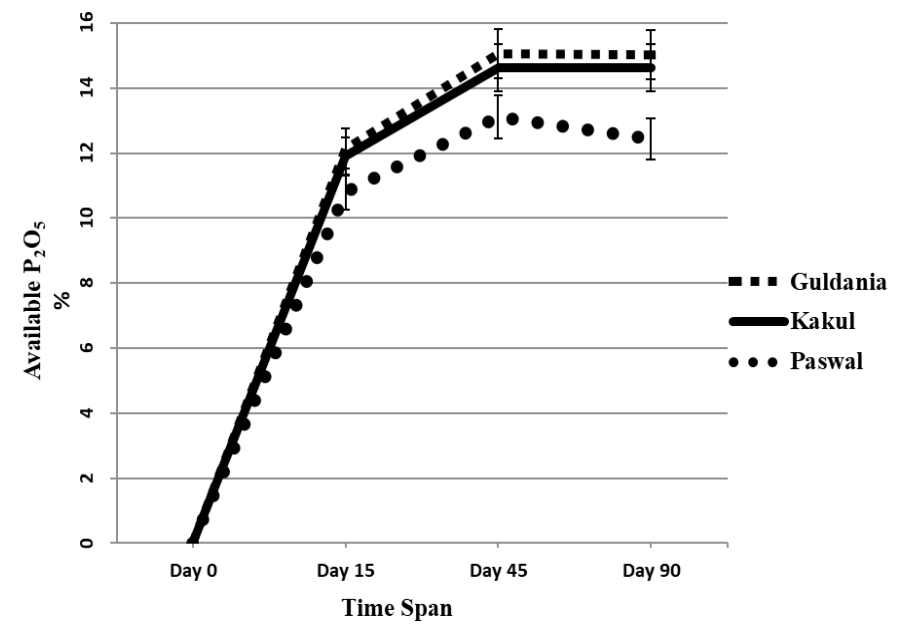

Figure 1: Periodic Trend of $P$ availability from various rock phosphate sources.

Periodic trend of $P$ availability from various rock phosphates

The time span effect on the $\mathrm{P}$ availability of various rock phosphates after acidulation process remained ascending up to day 90 (Figure 1). Guldania showed maximum $P$ availability (12.14\%) than Kakul(11.90\%) and Paswal (10.79) at day 15. Similarly, Guldania gave more $P$ availability (15.05\%) than Kakul (14.63\%) and Paswal (13.11\%) at day 45. Guldania showed highest $\mathrm{P}$ availability (15.03\%) than Kakul (14.63\%) and
Paswal (12.41\%) at day 90. The overall $\mathrm{P}$ availability was very sharp up to day 15 where $76.02 \%-76.19 \%$ of the available $\mathrm{P}$ content was recorded in Guldania, Kakul and Paswal irrespective of acid application. Guldania superseded in P availability over Kakul and Paswal by releasing $89.71 \%$ and $97.98 \%$ increased $\mathrm{P}$ respectively at day 15 . The $\mathrm{P}$ availability trend between day 15 to day 90 was increasing but the rate of increase was not as sharp as up to day 15 . The increase in P availability between day 45 and day 90 remained constant. The results are in accordance with the findings of Anonymous (2004) and The Pakistan Mineral Development Corporation (2006).

\section{Conclusions and Recommendations}

The result of these experiments showed that all the three rock phosphates released maximum $\mathrm{P}$ at different acid formulations. It is concluded that;

- Guldania area rock phosphate is more reactive than Kakul and Paswal. It results in comparatively more enriched SSP.

- Phosphorus availability remains increasing, after reaction up to day 45.

- The amount of dilution of sulfuric acid required for reacting $1 \mathrm{~kg}$ rock phosphate to release maximum $\mathrm{P}$ containing SSP.

\section{Acknowledgement}

Research for Agricultural Development Program (RADP) Pakistan Agricultural Research (PARC) is gratefully acknowledged for financial support to conduct this research.

\section{Author's Contribution}

Matiullah Khan: Implementation of experiment, lab and field work planning and supervision, assistance in write-up.

Humera Arif: Lab and field work, analyses of data, drafting paper.

Muhammad Rashid: Main supervisor of the study. Helped in planning, write-up and review of study.

Motsim Billah: Assisted in data analyses, lab analytical work and experiments layout.

Shoaib Ahmad: Assisted in data compilation, review of literature and an analyses planning.

\section{Conflict of interest}

The authors have declared no conflict of interest. 
References

Anonymous. 2004. Investment oriented study on minerals and mineral based industries. Experts Advis. Cell, Minist. Ind. Prod., GoP. pp. 113117.

Brady, N., 1990. The nature and properties of soils. $8^{\text {th }}$ edition. Macmillan Publ. Co., Inc. New York.

Chavarria, J.M., 1981. Hand book on phosphate fertilizers. ISMA limited, 28 Rue Marbeuf 75008 Paris.

Das, K.D., 2005. Introductory soil science. $4^{\text {th }}$ edition, Kalyani Publishers, New Dehli, India.

Fertilizer Manual. 1979. United Nations Industrial Development Organization (UNIDO) Vienna, Austria. International Fertilizer Development Centre (IFDC) Muscle Shoals, Alabama, USA. GOP. 2018. Economic survey of Pakistan (2014). Minist. Food Agric. Fed. Bur. Stat., GoP, Islamabad.

IPNI. 2008. Assessment of soil phosphorus status and management of phosphatic fertilizers to optimize crop production. IPNITECDOC-1272. Vienna.

Khan, M., S. Ahmad, M. Sharif, M. Billah and M. Aslam. 2012. Formulation of single super phosphate fertilizer from rock phosphate of Hazara, Pakistan. Soil Environ. 31(1): 96-99.

Lassis, M., N. Dadda and R. Rahmnia. 2015.
Dissolution of Djebel Onk phosphate ore using sulfuric acid. Environ. Nanotechnol. Monit. Manage. 4: 12-16. https://doi.org/10.1016/j. enmm.2015.03.002

Memon, K.S., 2005. Phosphorus requirement of Pakistani Soils in: Proc. XII Int. Forum Soil Taxonomy Agro Technol. Transfer I. Soil Survey of Pakistan, Lahore.

Olsen, S. R., and L. E. Sommers. 1982. Phosphorus. In A. L. Page (ed.), Methods of Soil Analysis, Agron. No. 9, part 2: Chemical and Microbiological Properties, 2nd ed., Am. Soc Madison Wisconsim. 403-430.

PMDC, 2006. Survey brief report on rock phosphate at Kakaul and Tarnwari. Islamabad. pp. 1-13.

Pakistan Standard, 1961. Specification for super phosphate fertilizer. Pakistan Standard Institution. 67: 4-6.

Rashid, A., 2005. Soil science. $3^{\text {rd }}$ edition. National book foundation, Islamabad, Pakistan.

Rabchevsky, G.A., 1997. Phosphate rock. US Geological Survey (Ed.), Mineral. Commod. Summ. 1997: 124-125.

Soltanpour, P.N. and S. Workman. 1985. Modification of the $\mathrm{NH}_{4} \mathrm{HCO}_{3}-\mathrm{DTPA}$ soil test to omit carbon black 1 . Commun. Soil Sci. Plant Anal., 10(11): 1411-1420. https://doi. org/10.1080/00103627909366996 